\title{
Use of the Growth Hormone Stimulation Test Result in the Management of Patients With a Short Stature
}

\author{
Moeber M. Mahzari 1, 2, 3 , Futun Al Joufi ${ }^{4,5}$, Shams Al Otaibi ${ }^{6}$, Esra Hassan ${ }^{2,} 3$, Emad Masuadi ${ }^{7}$ \\ 1. Medicine, College of Medicine, King Saud Bin Abdulaziz University for Health Sciences, Riyadh, SAU 2. Medicine, \\ Ministry of National Guard - Health Affairs, Riyadh, SAU 3. Medicine, King Abdullah International Medical Research \\ Center, Riyadh, SAU 4. Pediatrics, Ministry of National Guard - Health Affairs, Riyadh, SAU 5. Pediatrics, King Abdullah \\ International Medical Research Center, Riyadh, SAU 6. Otolaryngology, King Fahad Medical City, Riyadh, SAU 7. \\ Biostatistics, King Saud Bin Abdulaziz University for Health Sciences, Riyadh, SAU
}

Corresponding author: Moeber M. Mahzari, moeber@hotmail.com

\begin{abstract}
Introduction

A proportionate short stature (SS) assessment involves the documentation of normal growth hormone secretion via a growth hormone (GH) stimulation test. All available GH stimulation tests have some disadvantages. The decision to initiate GH therapy is dependent on multiple factors, including the $\mathrm{GH}$ stimulation test result. However, many patients receive GH therapy, even if they have a normal GH stimulation test result, with the indication of a presumed idiopathic SS.
\end{abstract}

Objective

In this study, we investigated the use of the GH stimulation test result in initiating GH therapy.

Method

A cross-sectional study was conducted with patients diagnosed with proportionate SS. Age, gender, insulinlike growth factor 1 (IGF-1) level, and GH stimulation test results were collected retrospectively from the electronic medical records. The main outcome variable was the decision related to prescribing GH therapy.

Results

A total of 286 patient charts were reviewed, and the majority $(n=201,64.6 \%)$ were male. For just less than half $(\mathrm{n}=136,47.6 \%)$, the result of the $\mathrm{GH}$ stimulation test was $\geqslant 10 \mathrm{ng} / \mathrm{mL}$, in a small proportion $(\mathrm{n}=53$, $18.5 \%$ ) the result was $<5 \mathrm{ng} / \mathrm{mL}$, and for the rest of the cohort, the result was $5.0-9.9 \mathrm{ng} / \mathrm{mL}$. The majority $(\mathrm{n}=219,70.4 \%)$ received GH therapy, irrespective of the GH stimulation test result. The odds ratio (OR) for GH treatment was 3.9 (CI: 1.79 - 8.49) and 3.0 (CI: 1.21 - 7.42) for patients with a result $<5 \mathrm{ng} / \mathrm{mL}$ and 5.0 $9.9 \mathrm{ng} / \mathrm{mL}$, respectively, compared to the group with a result of $\geqslant 10 \mathrm{ng} / \mathrm{mL}$. Review ended 10/09/2020 Published 10/16/2020

\section{(c) Copyright 2020}

Mahzari et al. This is an open access article distributed under the terms of the Creative Commons Attribution License CC-BY 4.0, which permits unrestricted use, distribution, and reproduction in any medium, provided the original author and source are credited.

Conclusion

GH therapy is frequently prescribed for patients with SS, irrespective of the GH stimulation test result. However, the group with SS with a result of $<9.9 \mathrm{ng} / \mathrm{mL}$ was more likely to receive GH therapy. The question of whether a GH stimulation test is required, in the context of SS, is debatable.

Categories: Endocrinology/Diabetes/Metabolism

Keywords: growth hormone, growth hormone stimulation test, short stature (ss)

\section{Introduction}

A short stature (SS) is a frequent concern presented to pediatricians and endocrinologists [1]. SS is defined as height less than two standard deviations below the median appropriate height for a population, taking into consideration the patient's gender and age. SS could also be defined as a height below the 3rd percentile on a growth chart, or a growth velocity below the 25 th percentile consistently over six to 12 months of observation [1-2]. The global prevalence of SS is 3\% [3]. The SS prevalence in Saudi children and adolescents is considered to be similar to the global prevalence, but the exact prevalence is not known [4]. SS is classified as disproportionate and proportionate SS. Disproportionate SS, a rare type, presents with short limbs, such as diastrophic dysplasia and chondrodysplasia punctata, or a short trunk, such as in mucopolysaccharidosis. The more prevalent normal variant SS is classified as the proportionate type, with normal proportionate growth of limbs and trunk. The causes of proportionate SS include prenatal causes (genetic disorders) and 
postnatal causes, such as growth hormone deficiency (GHD). GHD classically could be deficient in isolation or with other pituitary hormones [3].

The diagnosis of GHD is challenging due to the pulsatile nature of growth hormone secretion in the body. It is also dependent on age, gender, and body mass index (BMI). A single random measurement of growth hormone is rarely diagnostic. Biochemical growth hormone markers, such as the insulin-like growth factor 1 (IGF-1) and the IGF-binding protein 3 (IGFBP-3), have poor diagnostic values due to overlapping results of the markers in healthy and GHD patients. According to the Growth Hormone Research Society, one dependable growth hormone stimulation test is adequate to make the diagnosis. In the United States, an insulin tolerance test (ITT) is the gold standard stimulation test for adults with GHD [5]. The cut-off point for the diagnosis is a GH level of 3 to $5 \mathrm{ng} / \mathrm{mL}$ during acute hypoglycemia, i.e., less than $40 \mathrm{mg} / \mathrm{dL}$. However, ITT is contraindicated in coronary artery disease and epileptic patients. A major drawback of this test is that it requires close monitoring due to adverse effects, such as seizures and loss of consciousness. The glucagon stimulation test (GST) is an acceptable alternative test to ITT. GST is more potent in stimulating GH in comparison to other stimulation tests, such as clonidine. In addition, the intramuscular or subcutaneous route of administration of GST is more effective than the intravenous route. Reproducibility and safety are the main advantages of GST. The relatively long duration of the procedure, up to four hours, is considered a disadvantage of the test [5]. The clonidine stimulation test (CST) is the preferred test in diagnosing children with GHD [6]. Clinically, there is no standardized peak time with CST as the GH response peak time could be early or late. CST involves an oral dose of $150 \mu \mathrm{g} / \mathrm{m}^{2}$ of clonidine and the GH response is measured at successive periods of $0,30,45,60$, and 90 minutes. Measuring the GH response at different times can be financially demanding. Thakur et al. found that the 60 minutes post-CST measurement is the most important to exclude GHD (79.5\% specificity). The addition of the 90 minutes raises the test's specificity to $92.3 \%[6]$.

IGFs are GH-dependent peptide factors that mediate the actions of GH [7]. As IGFs levels remain steady during the day, it can be assessed with a single estimation [8]. The pulsatile section rhythm of GH and the fact that it is low most of the day mandates the stimulation test of GH [9]. However, IGF-1 in the pediatric age group lacks the specificity as a reduced level could occur in other endocrine and nutritional abnormalities [10-12]. In addition, it is significantly affected by the age and pubertal status of the patient as it could overlap with normality [13-15]. A number of studies concluded that IGF-1 in pediatric age doses does not correlate with the GH status [16-18]. In practice, more information related to the case is collected from a single IGF-1 and IGFBP-3 measurement, in combination with a single GH stimulation test. For a subnormal GH stimulation test result, a second stimulation test supports the differentiation between GHD and a normal SS [9]. The treatment for patients with SS due to GHD is GH injections. It should be noted that during the last decade, GH treatment for SS expanded and is indicated for almost all cases of proportionate SS, not only in patients with GHD [1]. Currently, patients with SS with a normal stimulation test (GHD not diagnosed based on the GH stimulation test) are candidates for GH treatment for presumed idiopathic SS. This change in GH indications over time may render the GH stimulation test redundant in the context of SS as most, if not all, the patients with proven proportionate SS are candidates to receive GH therapy. In this study, we assessed the impact of the GH stimulation test result on the decision to treat with GH in a relatively large group of patients with a diagnosis of SS.

\section{Materials And Methods}

A cross-sectional study was conducted using a retrospective chart review of patients attending endocrine clinics with a diagnosis of SS. The study was conducted at King Abdulaziz Medical City in Riyadh, Saudi Arabia. King Abdulaziz Medical City is one of the largest medical cities in Saudi Arabia with primary, secondary, and tertiary care facilities.

All patients, four to 18 years old, with a confirmed diagnosis of SS by an endocrinologist and who had a GH stimulation test of any type from 2000 to 2016 were included in the study. Patients with a comorbid condition, such as chronic kidney disease, as a cause of SS, were excluded from the study. The data collected included the age of diagnosis with SS, gender, type of GH stimulation test used, the GH response to the stimulation test, the IGF-1 level at diagnosis, and whether the patient received GH therapy or not. The main outcome variable was the categorical variable of treatment with GH or not. The data were collected with a structured data collection sheet and analyzed by the Statistical Package for Social Sciences (SPSS), v. 20 (IBM SPSS Statistics, Armonk, NY). Percentage and frequency were used to describe categorical variables and a mean and standard deviation for the numerical variables. A Chi-square test was used to compare the significance of the outcome variable between different groups. A statistical test with a p-value of less than 0.05 was considered statistically significant.

\section{Results}

A total of 286 patient charts were reviewed. The majority of the patients $(n=201,64.6 \%)$ were male and 175 patients $(56.3 \%)$ were $\geqslant 10$ years old (Table 1 ). 


\section{Cureus}

\begin{tabular}{|c|c|c|c|}
\hline Variable & Categories & $\mathbf{N}$ & $\%$ \\
\hline \multirow{2}{*}{ Gender } & Male & 201 & 64.6 \\
\hline & Female & 110 & 35.4 \\
\hline \multirow{2}{*}{ Age (years) } & $<10$ & 136 & 43.7 \\
\hline & $\geq 10$ & 175 & 56.3 \\
\hline \multirow{3}{*}{ Type of GH stimulation test } & Clonidine & 205 & 65.9 \\
\hline & Glucagon & 88 & 28.3 \\
\hline & ITT & 18 & 5.8 \\
\hline \multirow{3}{*}{ Peak GH after stimulation $(\mathrm{ng} / \mathrm{mL})$} & $10+$ & 136 & 47.6 \\
\hline & $5-9.9$ & 97 & 33.9 \\
\hline & $<5$ & 53 & 18.5 \\
\hline \multirow{2}{*}{ Pt given GH } & Yes & 219 & 70.4 \\
\hline & No & 92 & 29.6 \\
\hline IGF-1 level (ng/mL) (Mean \pm SD & $107.45 \pm 72.2$ & & \\
\hline
\end{tabular}

\section{TABLE 1: Demographical Data of the Patients}

GH: growth hormone; IGF-1: insulin-like growth factor 1; ITT: insulin tolerance test; SD: standard deviation

The most frequently used GH stimulation test was the clonidine stimulation test ( $\mathrm{n}=205,65.9 \%)$, followed by the GST $(n=88,28.3 \%)$, and only a small proportion $(n=18,5.8 \%)$ of the sample had an ITT. For less than half of the patients ( $\mathrm{n}=136,47.6 \%$ ), the GH stimulation test result was $\geqslant 10 \mathrm{ng} / \mathrm{mL}$. In a small proportion (n $=53,18.5 \%$ ), the result was $<5 \mathrm{ng} / \mathrm{mL}$. For the rest of the cohort, the result was between $5.0-9.9 \mathrm{ng} / \mathrm{mL}$.

Table 2 displays the proportions of the patients who received GH treatment, grouped by their GH stimulation test result. The majority of the sample $(n=219,70.4 \%)$ received GH therapy. For the $\geqslant 10 \mathrm{ng} / \mathrm{mL}$ stimulation group $(\mathrm{n}=136)$, more than half $(\mathrm{n}=79,58.1 \%)$ received GH treatment; in the $<5 \mathrm{ng} / \mathrm{mL}$ stimulation group $(\mathrm{n}=53), 46(86.6 \%)$ patients received GH. A similar pattern was also seen in the $5.0-9.9$ $\mathrm{ng} / \mathrm{mL}$ group $(\mathrm{n}=97)$, with $84(86.6 \%)$ receiving $\mathrm{GH}$. The outcome variable (GH therapy prescribed or not) assessed with a Chi-square test was statistically different between the groups ( $\mathrm{p}$-value of $<0.5$ ).

\begin{tabular}{|c|c|c|c|c|c|}
\hline \multirow[b]{3}{*}{ Peak GH after stimulation $(\mathrm{ng} / \mathrm{mL})$} & \multicolumn{4}{|c|}{ Patient given GH } & \multirow{3}{*}{ P-value } \\
\hline & \multicolumn{2}{|l|}{ Yes } & \multicolumn{2}{|l|}{ No } & \\
\hline & $\mathrm{N}$ & $\%$ & $\mathrm{~N}$ & $\%$ & \\
\hline $10+$ & 79 & 58.1 & 57 & 41.9 & \multirow{4}{*}{$<0.001$} \\
\hline $5-9.9$ & 84 & 86.6 & 13 & 13.4 & \\
\hline$<5$ & 46 & 86.8 & 7 & 13.2 & \\
\hline Total & 209 & 73.1 & 77 & 26.9 & \\
\hline
\end{tabular}

TABLE 2: The Association Between the Peak Growth Hormone (GH) After Stimulation and Whether GH Was Given or Not

The mean level of IGF-1 at the time of diagnosis was not significantly different between the groups who received or did not receive $\mathrm{GH}$ (108 versus $105 \mathrm{ng} / \mathrm{mL}$ ).

The only factor that significantly affecting the GH therapy, was a GH stimulation result $9.9 \mathrm{ng} / \mathrm{mL}$ or lower. 
The odds ratio (OR) to receive $\mathrm{GH}$ treatment in patients with a result $<5 \mathrm{ng} / \mathrm{mL}$ was 3.9 (CI: 1.79 - 8.49) when the stimulated $\mathrm{GH} \geqslant 10 \mathrm{ng} / \mathrm{mL}$ group was used as the reference group in the logistic regression analysis. The same pattern was observed with an OR of 3.0 (CI: $1.21-7.42$ ) for the $5.0-9.9 \mathrm{ng} / \mathrm{mL}$ group, when referenced to the $\geqslant 10 \mathrm{ng} / \mathrm{mL}$ group. Age, gender, and IGF-1 level at the time of the diagnosis did not influence the GH therapy significantly (Table 3).

\begin{tabular}{|c|c|c|c|c|c|}
\hline & & \multirow{2}{*}{ P-value } & \multirow{2}{*}{ OR } & \multicolumn{2}{|c|}{$95 \% \mathrm{Cl}$ for OR } \\
\hline & & & & Lower & Upper \\
\hline \multirow{2}{*}{ Gender } & Male & 0.432 & 0.75 & 0.37 & 1.54 \\
\hline & Female $^{\star}$ & & 1 & & \\
\hline \multirow{3}{*}{ Peak GH after stimulation $(\mathrm{ng} / \mathrm{mL})$} & $<5$ & 0.001 & 3.9 & 1.79 & 8.49 \\
\hline & $5-9.9$ & 0.018 & 3 & 1.21 & 7.42 \\
\hline & $10+^{\star}$ & & 1 & & \\
\hline \multirow{2}{*}{ Age (years) } & $<10$ & 0.628 & 1.19 & 0.60 & 2.36 \\
\hline & $\geq 10^{\star}$ & & 1 & & \\
\hline IGF-1 level at diagnosis & & 0.51 & 1.0 & 0.99 & 1.00 \\
\hline
\end{tabular}

TABLE 3: Logistic Regression of Gender, Age, IGF-1 Level, and Growth Hormone (GH) Stimulation Result

Dependent variable is the status of growth hormone therapy (whether GH was given or not)

* is the reference group

CI: confidence interval; IGF-1: insulin-like growth factor 1; OR: odds ratio

\section{Discussion}

The decision to treat SS patients with GH is, to a large extent, subjective and is based on multiple variables. One of these variables is the result of the GH stimulation test, which is indicated in all patients with proportionate SS. It is noteworthy that GH treatment is justified in all patients with SS if there are no contraindications. Even patients with a normal growth hormone stimulation are candidates for GH treatment for presumed idiopathic SS [1]. The objective of this study was to assess the impact of the GH stimulation test results on the use of GH therapy in a large cohort of patients with SS at a tertiary care center, considering other available variables.

The study results indicated that the majority of the patients in this study received GH treatment, regardless of the GH stimulation test result, supporting the notion that GH therapy is an option for all SS patients if there are no contraindications. However, there was a significant difference between the groups with a test result $<10 \mathrm{ng} / \mathrm{mL}$ as more of this group received GH therapy compared to the group with a result $\geqslant 10 \mathrm{ng} / \mathrm{mL}$. The difference was expected. However, if we focus on the group with a result $\geqslant 10 \mathrm{ng} / \mathrm{mL}$, the majority also received GH therapy despite the normal stimulated GH test result. A small proportion (13\%) of the patients with a subnormal GH response did not receive $\mathrm{GH}$ therapy, indicating that the $\mathrm{GH}$ stimulation test result is not the only or the most important factor influencing the GH therapy decision.

GH treatment should be initiated as early as possible to maximize the benefit of GH and to promote the normalization of the stature prior to adulthood, taking into consideration the child's genetic background [19-20]. If the logistics required for a GH stimulation test, the possible risks, and the delay of the initiation of GH therapy due to the GH stimulation test are considered, we submit that the GH stimulation test could be omitted in most patients with SS. Indeed, in countries in the Middle East where the GH stimulation test is not readily available, patients may have to wait many months for the test before initiating GH therapy. This delay, especially in patients who are approaching complete bone maturity, might be harmful. The timely initiation of GH therapy without a GH stimulation test is justified due to the practice to initiate GH therapy regardless of the test result.

The importance of the GH stimulation test in the context of SS is to identify patients with GHD who will require longer GH therapy, even after height completion. However, the dependence on the GH stimulation test as the only way to confirm or diagnose GHD is debatable. The use of GH replacement after growth 
completion in patients with possible isolated GHD as children or adolescents is not recommended unless the GHD is still present after height completion. In patients with an isolated GH deficiency, the GH stimulation test should be repeated at approximately 18 years to guide the decision to continue with GH replacement, highlighting the minor impact of the initial GH stimulation test on the long-term continuation of GH therapy [21]. Another important argument is that the GH stimulation test result may guide the GH dose, but this application is also questionable as there is an overlap in the GH dose required in specific conditions. The recommendation is to dose GH as weight-based or body surface area (BSA)-based, and it is, to a large extent, physician and institution-dependent [22-26]. The IGF-1 can serve as a tracking biomarker for the GH therapy, to evaluate its effectiveness, monitor adherence, and titrate the dose as appropriate [20, 26].

Though the study included a large sample from a single tertiary center, we acknowledge the limitations of conducting a retrospective study, which may lack important data required for a robust conclusion. In particular, accurate data on the patients' height, growth velocity, and height change over time, in relation to the GH stimulation test results and their effect on the GH therapy decision, were not available. Additional prospective studies, focusing on the impact of the GH stimulation test on the SS treatment, particularly in patients with a normal GH stimulation result, are required. It is essential to determine the utility of the GH stimulation test in relation to the initiation and guidance of GH therapy and the disadvantage of delaying the timely initiation of GH therapy.

\section{Conclusions}

GH therapy is frequently prescribed for patients with SS, irrespective of the GH stimulation test result. However, the group with SS with a result of $<9.9 \mathrm{ng} / \mathrm{mL}$ was more likely to receive GH therapy. The question of whether a GH stimulation test is required, in the context of SS, is debatable.

\section{Additional Information}

\section{Disclosures}

Human subjects: Consent was obtained by all participants in this study. King Abdullah International Medical Research Center Ethics Committee issued approval RC17/151/R. Animal subjects: All authors have confirmed that this study did not involve animal subjects or tissue. Conflicts of interest: In compliance with the ICMJE uniform disclosure form, all authors declare the following: Payment/services info: All authors have declared that no financial support was received from any organization for the submitted work. Financial relationships: All authors have declared that they have no financial relationships at present or within the previous three years with any organizations that might have an interest in the submitted work. Other relationships: All authors have declared that there are no other relationships or activities that could appear to have influenced the submitted work.

\section{References}

1. Cohen P, Rogol A, Deal C, et al.: Consensus statement on the diagnosis and treatment of children with idiopathic short stature: a summary of the Growth Hormone Research Society, the Lawson Wilkins Pediatric Endocrine Society, and the European Society for Paediatric Endocrinology Workshop. J Clin Endocrinol Metab. 2008, 93:4210-4217. 10.1210/jc.2008-0509

2. Reed ML, Merriam GR, Kargi AY: Adult growth hormone deficiency - benefits, side effects, and risks of growth hormone replacement. Front Endocrinol (Lausanne). 2013, 4:64. 10.3389/fendo.2013.00064

3. Lifshitz F: Pediatric Endocrinology, fifth edition. Lifshitz F (ed): CRC Press, New York; 2006. http://books.google.com/books? id=NUBZDwAAQBAJ \& printsec=frontcover \&dq=Pediatric+Endocrinology.+ Fifth+edition \&hl=en \&new....

4. El Mouzan MI, Al Herbish AS, Al Salloum AA, Foster PJ, Al Omer AA, Qurachi MM: Prevalence of short stature in Saudi children and adolescents. Ann Saudi Med. 2011, 31:498-501. 10.4103/0256-4947.84628

5. Yuen KC, Tritos NA, Samson SL, Hoffman AR, Katznelson L: American Association of Clinical Endocrinologists and American College of endocrinology disease state clinical review: update on growth hormone stimulation testing and proposed revised cut-point for the glucagon stimulation test in the diagnosis of adult growth hormone deficiency. Endocr Pract. 2016, 22:1235-1244. 10.4158/EP161407.DSCR

6. Thakur DS, Bhagwat NM, Bhide MM, et al.: Clonidine stimulation test: Is single best time point, convenient yet efficacious?. Indian J Endocrinol Metab. 2018, 22:511-514.

7. Daughaday WH, Rotwein P: Insulin-like growth factors I and II. Peptide, messenger ribonucleic acid and gene structures, serum, and tissue concentrations. Endocr Rev. 1989, 10:68-91. 10.1210/edrv-10-1-68

8. Rosenfeld RG, Lamson G, Pham H, et al.: Insulinlike growth factor-binding proteins. Recent Progress In Hormone Research, Proceedings of the 1989 Laurentian Hormone Conference. Clark JH (ed): Academic Press, San Diego; 1990. 46:99-163. 10.1016/b978-0-12-571146-3.50009-2

9. Shalet SM, Toogood A, Rahim A, Brennan BM: The diagnosis of growth hormone deficiency in children and adults. Endocr Rev. 1998, 19:203-223. 10.1210/edrv.19.2.0329

10. Soliman AT, Hassan AE, Aref MK, Hintz RL, Rosenfeld RG, Rogol AD: Serum insulin-like growth factors I and II concentrations and growth hormone and insulin responses to arginine infusion in children with protein-energy malnutrition before and after nutritional rehabilitation. Pediatr Res. 1986, 20:1122-1130. 10.1203/00006450-198611000-00012

11. Baxter RC, Brown AS, Turtle JR: Radioimmunoassay for somatomedin C: comparison with radioreceptor assay in patients with growth-hormone disorders, hypothyroidism, and renal failure. Clin Chem. 1982, 28:488-495. 
12. Tamborlane WV, Hintz RL, Bergman M, Genel M, Felig P, Sherwin RS: Insulin-infusion-pump treatment of diabetes: influence of improved metabolic control on plasma somatomedin levels. N Engl J Med. 1981, 305:303-307. 10.1056/NEJM198108063050602

13. Luna AM, Wilson DM, Wibbelsman CJ, Brown RC, Nagashima RJ, Hintz RL, Rosenfeld RG: Somatomedins in adolescence: a cross-sectional study of the effect of puberty on plasma insulin-like growth factor I and II levels. J Clin Endocrinol Metab. 1983, 57:268-271. 10.1210/jcem-57-2-268

14. Rosenfield RI, Furlanetto R, Bock D: Relationship of somatomedin-C concentrations to pubertal changes . J Pediatr. 1983, 103:723-728. 10.1016/S0022-3476(83)80465-X

15. Juul A, Bang P, Hertel NT, et al.: Serum insulin-like growth factor-I in 1030 healthy children, adolescents, and adults: relation to age, sex, stage of puberty, testicular size, and body mass index. J Clin Endocrinol Metab. 1994, 78:744-752. 10.1210/jcem.78.3.8126152

16. Tillmann V, Buckler JM, Kibirige MS, et al.: Biochemical tests in the diagnosis of childhood growth hormone deficiency. J Clin Endocrinol Metab. 1997, 82:531-535. 10.1210/jcem.82.2.3750

17. Moore DC, Ruvalcaba RH, Smith EK, Kelley VC: Plasma somatomedin-C as a screening test for growth hormone deficiency in children and adolescents. Horm Res. 1982, 16:49-55. 10.1159/000179484

18. Reiter EO, Lovinger RD: The use of a commercially available somatomedin-C radioimmunoassay in patients with disorders of growth. J Pediatr. 1981, 99:720-724. 10.1016/S0022-3476(81)80391-5

19. Rose SR, Cook DM, Fine MJ: Growth hormone therapy guidelines: clinical and managed care perspectives . Am J Pharm Benefits. 2014, 6:e134-e146.

20. Grimberg A, DiVall SA, Polychronakos C, et al.: Guidelines for growth hormone and insulin-like growth factor-I treatment in children and adolescents: growth hormone deficiency, idiopathic short stature, and primary insulin-like growth factor-I deficiency. Horm Res Paediatr. 2016, 86:361-397. 10.1159/000452150

21. Molitch ME, Clemmons DR, Malozowski S, Merriam GR, Vance ML; Endocrine Society: Evaluation and treatment of adult growth hormone deficiency: an Endocrine Society clinical practice guideline. J Clin Endocrinol Metab. 2011, 96:1587-1609. 10.1210/jc.2011-0179

22. Root AW, Dana K, Lippe B: Treatment of growth hormone-deficient infants with recombinant human growth hormone to near-adult height: patterns of growth. Horm Res Paediatr. 2011, 75:276-283. 10.1159/000322881

23. Thomas M, Massa G, Bourguignon JP, et al.: Final height in children with idiopathic growth hormone deficiency treated with recombinant human growth hormone: the Belgian experience. Horm Res. 2001, 55:88-94. 10.1159/000049976

24. Mauras N, Attie KM, Reiter EO, Saenger P, Baptista J: High dose recombinant human growth hormone (GH) treatment of GH-deficient patients in puberty increases near-final height: a randomized, multicenter trial. J Clin Endocrinol Metab. 2000, 85:3653-3660. 10.1210/jcem.85.10.6906

25. De Luca F, Maghnie M, Arrigo T, Lombardo F, Messina MF, Bernasconi S: Final height outcome of growth hormone-deficient patients treated since less than five years of age. Acta Paediatr. 1996, 85:1167-1171.

26. Juul A, Bernasconi S, Clayton PE, Kiess W, DeMuinck-Keizer Schrama S; Drugs and Therapeutics Committee of the European Society for Paediatric Endocrinology (ESPE): European audit of current practice in diagnosis and treatment of childhood growth hormone deficiency. Horm Res. 2002, 58:233-241. $10.1159 / 000066265$ 